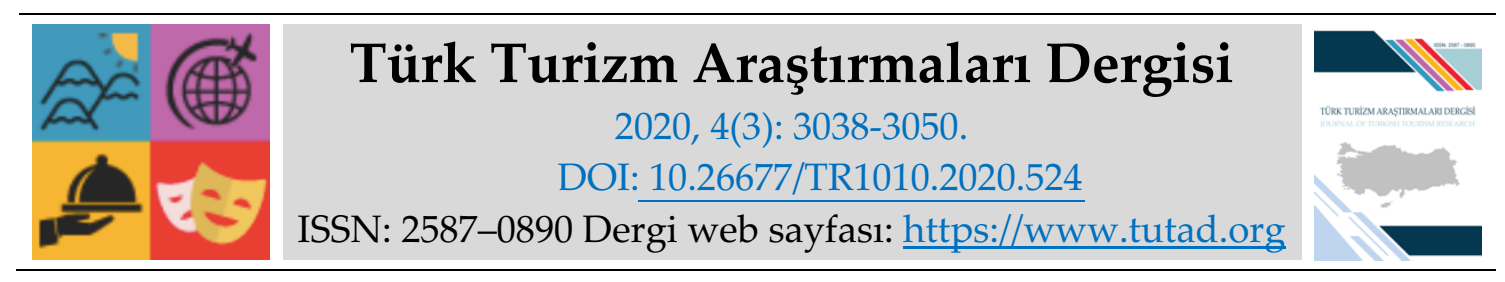

KAVRAMSAL MAKALE

\title{
Güvenlik Özgürlük İkileminde Küresel Turizmin Risk ve Fırsatları
}

Dr. Ertan ÖZÇOBAN, Hacı Bayram Veli Üniversitesi, Ankara, e-posta: ertan.ozcoban@hbv.edu.tr ORCID: https://orcid.org/0000-0001-8282-1731

Hulusi GÖLPINAR, Doktora Öğrencisi, Polis Akademisi Güvenlik Bilimleri Enstitüsü, Ankara, e-posta: hulusigolpinar@gmail.com

ORCID: https://orcid.org/0000-0003-0141-9893

\section{$\ddot{O} z$}

Demokratik devletler hem güvenliği yerine getirip aynı zamanda özgürlüklerin en az düzeyde kısıtlanması noktasında denge arayışında iken turizm faaliyetlerinin geliştirilmesi ve denetlenmesinde de önemli bir rol üstlenmektedir. Küresel turizm, devletlerin istihbarat faaliyetleri, terörle mücadele, ekonomik güvenlik, doğal ve kültürel varlıkların güvenliğinin sağlanması ve asayiş olaylarının denetimi gibi konularda tehdit unsurları oluştururken aynı zamanda bu alanlar için de belirli fırsatlar içermektedir. Bu doğrultuda çalışmanın amacı, dünya ekonomisinde en hızlı büyüyen sektörlerden birisi olan turizm sektörünün, devletler açısından güvenlik-özgürlük dengesinde meydana getirdiği risk ve fırsatların analizidir. Çalışmada, nitel araştırma yöntemi kullanılmış ve bu alanda yapılan bilimsel çalışmalardan faydalanılarak, alanyazın taranmıştır. Bu kapsamda, turizm ve güvenlik gibi iki farklı bilim dalının teorik kesişim noktaları güvenlik yaklaşımı çerçevesinde değerlendirilmiştir. Araştırmada, turizmin, özgürlük ve güvenlikle olan ilişkisinde, tek yönlü bakış açısının yeterli olmayacağı, yerel halkın turizm destinasyonlarındaki fırsat ve risk dengesinin korunmasında önemli bir güç olduğu ve turizm endüstrisinin geliştirilmesi için devletlerin güvenlik-özgürlük dengesini kuran temel politika ekseninin, müdahaleci değil önleyici güvenlik yaklaşımları ile desteklenmesi gerektiği sonucuna ulaşılmıştır.

Anahtar Kelimeler: Turizm, Güvenlik, Özgürlük, Terörle Mücadele, İstihbarat.

Makale Gönderme Tarihi: 23.03.2020

Makale Kabul Tarihi: 04.07.2020

\section{Önerilen Atıf:}

Özçoban, E. ve Gölpınar, H. (2020). Güvenlik Özgürlük İkileminde Küresel Turizmin Risk ve Fırsatları, Türk Turizm Araştırmaları Dergisi, 4(3): 3038-3050.

(C) 2020 Türk Turizm Araştırmaları Dergisi. 


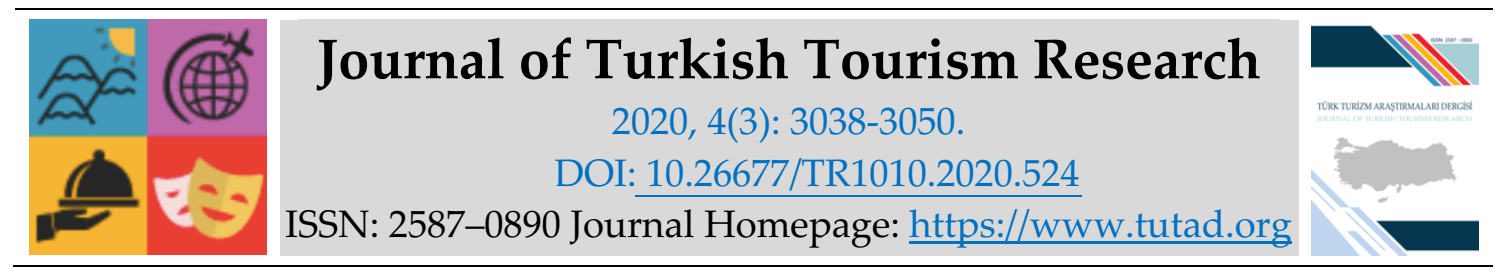

CONCEPTUAL PAPER

\title{
Risks and Opportunities of Global Tourism in the Frame of Security-Liberty Dilemma
}

Dr. Ertan ÖZÇOBAN, Hacı Bayram Veli University, Ankara, e-mail: ertan.ozcoban@hbv.edu.tr ORCID: https://orcid.org/0000-0001-8282-1731

Hulusi GÖLPINAR, PhD. Student, Police Academy Institute of Security Sciences, Ankara, e-mail: hulusigolpinar@gmail.com

ORCID: https://orcid.org/0000-0003-0141-9893

\begin{abstract}
The subject of this article is an analysis of the risks and opportunities created by tourism which is one of the fastest growing sectors in the world economy, in the frame of security-liberty balance for states. Democratic states play an important role in the development and supervision of tourism activities, while seeking balance both in fulfilling security and limiting their freedom to a minimum. The main argument put forward by the article is that while global tourism poses threatening issues such as the intelligence activities of the states, the fight against terrorism, economic security, security of natural and cultural assets and control of public order events, it also includes certain opportunities for these areas. In order to prove this argument, the researchers conducted in different disciplines were brought together and analyzed within the framework of the security approach.
\end{abstract}

Keywords: Tourism, Security, Liberty, Counter-terrorism, Intelligence.

Received: 23.03 .2020

Accepted: 04.07.2020

\section{Suggested Citation:}

Özçoban, E. and Gölpınar, H. (2020). Risks and Opportunities of Global Tourism in the Frame of Security-Liberty Dilemma, Journal of Turkish Tourism Research, 4(3): 3038-3050.

(C) 2020 Türk Turizm Araştırmaları Dergisi. 


\section{GİRIŞ}

Küreselleşmeye paralel biçimde ulaşım endüstrisinin gelişimi ile birlikte 20. yüzyıldan itibaren belirgin bir yükselişe geçen turizm sektörü, 21. yüzyılda da dünya ekonomisinin önde gelen bileşenlerinden biri olmuştur. Küresel ekonominin en büyük paydaşlarından olmakla birlikte beraberinde trafik, tarım, ticaret, kentsel planlama, enerji endüstrisi ve bilgi teknolojileri gibi ekonominin diğer pek çok sektörleriyle de yakından ilgilidir (Mirovic vd., 2014:21). Diğer taraftan turizm, ülke ekonomileri açısından sağladığı fırsatlarla birlikte devletlere doğal ve kültürel mirasların korunması, ulaşım güvenliğinin ve konaklama güvenliğinin sağlanması gibi önemli sorumluluklar yüklemektedir.

Turizm, boş zaman kavramının nasıl kullanılacağına ilişkin ekonomik kararlara dayalı sosyal ve ekonomik bir olgudur (Kozak vd., 2014:7). Turizmin istihdam olanakları sağlaması, ülkelere döviz girdisi oluşturması, gerçekleşen turizm hareketiyle ülkelere vergi sağlaması, turizm hareketiyle ilişkili yapılan yatırımlar gibi ekonomiye birçok açıdan katkısı bulunmaktadır (Bahar vd.,2013:12). Diğer sektörlerin gelişmesinde de önemli rol oynayan turizm sektörü, ülkelerin alt ve üst yapılardaki eksikliklerin tamamlanmasını sağlayan bir konumdadır (Tutar vd., 2013:25). Turizm ülke ve bölgeler üzerindeki geliştirici katkısı, bu bölgelerde yaşayan yerel halkın için büyük bir istihdam fırsatı yaratmaktadır (Ünlüönen ve Şahin, 2011:22). Birleşmiş Milletler Dünya Turizm Örgütü verilerine göre, 2019 yılı itibariyle dünyada istihdamın yaklaşık \%10'u turizm sektöründe gerçekleşmekte olup turizmden elde edilen gelir ülkelerin ortalama ihracat gelirlerinin yaklaşık \%7'sini oluşturmaktadır. Yine aynı verilere göre 1950 yılında 25 milyon kişi olan küresel turist sayısı 2019 itibariyle 1,5 milyar kişiye ulaşmış olup bu rakamın 2030 yılı itibariyle 1,8 milyar kişi olması beklenmektedir (UNWTO, 2020).

İçerdiği ekonomik değerler ve sıcak para hareketliliği açısından bu kadar önemli olan turizm sektörü küreselleşmenin en önemli unsurunu oluştururken aynı zamanda devletler açısından da pek çok güvenlik risk ve tehditlerini de beraberinde getirdiği değerlendirilmektedir. Çünkü, demokratik rejimlerin başa çıkması gereken önemli sorunlar arasında şüphesiz güvenlik-özgürlük dengesinin sağlanması gelmektedir. Bir diğer deyişle, demokratik ülkelerin sınırları içerisinde güvenliği en geniş biçimde sağlarken aynı zamanda en dar biçimde özgürlüklere müdahale etmeleri beklenmektedir. Söz konusu durum, kendi içinde oldukça hassas bir denge içermektedir; keza güvenlikçi politikalarla özgürlükçü uygulamaların denge içinde bir arada sürdürülebilmesi her zaman mümkün görülmemektedir.

Özellikle turizm sektörü, devletler açısından güvenlik-özgürlük dengesinin en fazla gözetilmesi gereken alanlardan birini oluşturmaktadır. Bir ülkenin turizminin gelişmesi seyahat özgürlüğü başta olmak üzere bireysel hak ve özgürlüklerin teminat altında olma garantisiyle yakından ilişkilidir. Diğer taraftan yurt içi ve yurt dışı insan hareketliliğinin varlığı aynı zamanda bizatihi kendi içerisinde güvenlik risk ve tehditleri de oluşturmaktadır. Durum böyle olduğunda hem devlet güvenliği hem de bireylerin güvenliği adına gözetimci yaklaşımlar ve denetimler önem kazanırken bu gözetleme ve denetleme faaliyetlerinin yerli-yabancı turistlerin de temel hak ve özgürlüklerini kısitlamaması beklenmektedir. Bu hassas dengenin gözetilmesinin ana prensibi ise müdahaleci güvenlik yerine önleyici güvenlik yaklaşımlarıdır ki bu konuda ülkeler arası ve ülke içi istihbarat faaliyetleri ve bilgi paylaşımı önem arz etmektedir.

Bu doğrultuda, çalışmada, dünya ekonomisinde en hızlı büyüyen sektörlerden birisi olan turizm sektörünün, devletler açısından güvenlik-özgürlük dengesinde meydana getirdiği risk ve fırsatların analiz edilmesi amaçlanmıştır. Güvenlik ve özgürlük kavramları, turizmin özgürlükle ilgili temel unsurları ve turizmin devletler açısından içerdiği güvelik riski ve tehditleri olmak üzere üç bölümden oluşan çalışma sonucunda bir durum değerlendirmesi yapılmış, öneriler getirilmiş ve bundan sonraki bilimsel çalışmalar için katkı sağlaması hedeflenmiştir. 


\section{GÜVENLİK ve ÖZGÜRLÜĞE KAVRAMSAL BİR BAKIŞ}

Toplumların güvenlik ihtiyaçlarının ve kamu düzeninin sağlanabilmesinin sonucu olarak ortaya çıkan devlet mekanizmasının, toplumsal dinamikleri, siyasal oluşumları, uygarlıkları ve uluslararası ilişkileri de dönüştürdügünü ileri sürmek mümkündür. Önce mağara kapıları, ardından kaleler, ardından sınırlar inşa eden insanlık güvenlik ihtiyacı ile kabile hayatından uluslararası topluma seyreden bir medeniyet ilerlemesini de eş zamanlı gerçekleştirmiştir. Devletli yaşama geçişin insan hayatında neden olduğu kapsamlı değişim, güvenlik ihtiyacı açısından da yaşanmış ve böylece güvenliğin içeriği ve temin yöntemi devlet tarafından belirlenir olmuştur (Haspolat, 2010: 24). Güvenlik gereksinimi, devlet aygıtına ihtiyacın temel nedenlerinden biridir. Özellikle askeri açıdan tanımlanan ulusal güvenlik, tarihsel kronolojide alanyazına hâkim olmuştur. Temel ilgi alanı ise devletlerin, tehditlere karşı koyabilecek askeri imkân ve yetenekler üzerine yoğunlaşmış olan eğilimleridir (Baylis, 2008: 73). Bu noktadan hareketle; devletin var olma sebeplerinden birinin güvenliğin sağlanması kapsamında devlete olan ihtiyacın perçinlenmesi ve meşruiyet zeminin vatandaşların korunmaya olan ihtiyacı olduğu görülmektedir (Öz Yıldız, 2017).

Güvenlik kavramı, devlet, birey ve toplum ilişkisi ekseninde, toplumların can ve mallarının olası tehlikelere karşı korunması ile sınırlandırıldığında, bu sürecin başarılı koordinasyonu, bireylerdeki kamu düzeni hissiyatına inanış ve bu olguya ilişkin meşruiyetin olgunlaşması ile mümkün olabilecektir. (Öz Yıldız, 2017; Erdoğan, 2013). Devletin bizatihi kendisi, bireylerin güvenlik algısı üzerindeki gücünden ve bireylerin bunu "hissetmesinden" beslenmektedir (Öz Yıldız, 2019:136). Bu noktada öne çıkan temel yüklem, "hissetme" durumudur. Bunun en temel sebebi, günümüzde güvenlik anlayışının, objektif ve fiziki durumlar kadar hissetme gibi kaygan bir zeminde kendini göstermesidir. Bir toplumdaki güvenlik inşasının, yalnızca, kişilerin güvenlik algı durumlarına dayanarak tesis edilemeyeceği ve güvenliğin, profesyonelce planlanmış bir stratejiler bütünü olduğu görülmektedir. Güvenliğin algısal durumunun oluşması ise beraberinde özgürlük durumunun varlığını esas kılmaktadır.

Özgürlük kavramının, düşün ve eylem kararlarının herhangi bir kısıtlamadan muaf olması hali olduğu düşünüldüğünde, bu kavramın, insanlığın felsefe başta olmak üzere pek çok beşeri bilimin konusu olduğu görülmektedir. Özgürlük, bireyin, herhangi bir kısıtlama ve zorlamanın olmaksızın; düşünme, davranma, kendi iradesine, kendi düşüncesine dayanarak karar vermesi durumu olarak tanımlanabilir (Öz Yıldız, 2017:52). Asıl sorun ise özgürlük ve güvenlik arasında kurulan ilişki biçiminde sezilmektedir. Özgürlük kavramı, liberalizmin temel doktrinlerinden olmasına rağmen bununla sınırlı olmadığı bir gerçektir. Demokrasilerde yaşamsal önemde bir ilke olarak benimsenen özgürlük aynı zamanda güvenlik ile anlam kazanmaktadır. Çünkü bireylerin ancak güvenli ortamda özgürce hareket edebilecekleri ve özgürlüklerini teminat altına alabilecekleri kabul edilmektedir. Erdoğan (2013:23) bu durumu şu şekilde ifade etmektedir:

“Özgürlük ile güvenlik çoğu durumda birbirini tamamlarlar, bunlar birbirinin rakibi olmaktan ziyade birbirinin ön şartları durumundadırlar. Özgürlüğün yokluğu güvenliğin yokluğunu getirebilir, güvenliğin yokluğu da özgürlüğün. Bu bağlamda, güvenliğin bazı temel şartları olmadan kişinin özgürlüğe sahip olmasından söz etmek anlamlı değildir. Güvenlik ile özgürlük karşılıklı olarak birbirine bağlıdırlar ama belli şartlar altında karşılıklı olarak birbirlerini tehdit de ederler. Yine bu görüsse göre, bir bireyin özgürlük ve güvenlik çıarları hemen hemen her zaman birlikte gider; nispeten az tedbir bir kişiyi daha güvende kılarken onu daha az özgür yapar. Bir kişinin güvenliğini artıran çoğu tedbir aynı zamanda onun özgürlüğünü de artıracaktır. Çünkü, kişi eğer fiziksel olarak daha güvende olursa istediklerini yapmakta da daha özgür olacaktır." 
Devletlerin, özgürlük ve güvenlik arasındaki tercih yönelimlerinin yoğunluğunu belirleyen asıl unsurun zemininde güvenlik-özgürlük ikilemine dayalı düşünsel tartısmaların yer aldığı söylenebilir. Devlet merkezli güvenlik anlayışıyla birey merkezli özgürlük anlayışının karşı karşıya gelmesi durumunda devletin önceliği kaçınılmaz bir biçimde güvenlikten yana olacaktır. II. Dünya Savaşı'ndan sonra otokratik rejimlerin ülke yönetimlerindeki etkisinin, 1990'lı yıllarla birlikte demokratik bir dönüşüme doğru evrildiği dönüşüm yaşadığı ve bu kapsamda da güvenlik anlayışına, daha derin, karmaşık ve geniş bir anlam yüklendiğini söylemek mümkündür (Hayes, 2005). Bu süreçte, iç güvenlik meselelerinin askeri bir mesele olmaktan çıkarak, çok daha fazla sivil bir mesele haline büründüğü görülmektedir. Birbirinden farklı bileşenlerin oluşturduğu bir yapı kazanan iç güvenlik meselelerinin çözümü, özellikle "özgürlük ve güvenliği" aynı ölçüde talep eden, toplumlarda, devletler açısından önemli sorunlarından biri haline gelmiştir. (Hayes, 2005).

1990'lara kadar, toplumlarda mevcut olmayan ya da ileriye dönük etkileri hissedilmeyen iç isyanlar, terörizm, yasadışı göç, salgın hastalıklar, doğal afetler, insan hakları ihlalleri, sosyal eşitsizlik ve fakirlik, yasadışı uyuşturucu ticareti, silah kaçakçılığı gibi pek çok tehdit, artık günümüzün rutin tehditleri arasındadır.(Koçak ve Memiş, 2017) Turizm açısından bakıldığında ise kişilerin bireysel inisiyatifleri noktasında hareketliliği yeni güvenlik tehditlerinin hem sebebi hem sonucu olabilmektedir. Gözetlenmesi ve denetlenmesi mümkün olmayan insan hareketliliği ve kısa süreli turistik yerleşimler beraberinde çeşitli yasadışı faaliyetlere de zemin hazırlayabilmektedir. Diğer taraftan da turistik faaliyetler kapsamında insan hareketliliğinin güzergâh seçimi, güvenli ülke ve seyahat noktalarına yönelik olmaktadır. Bu yeni güvenlik tehditleriyle mücadelede devletler geleneksel mücadele yöntemlerini sürdürdüklerinde ise hem etkisiz kalmakta hem de demokratik sistem içinde bireyler üzerindeki meşruiyetlerini kaybetme tehlikesine girmektedirler. Bu nedenle devletler bir yandan güvenliği sağlamak adına kurumsal anlamda uluslararası işbirliği ve dayanışma içine girmekte, diğer yandan da yönetişim, hukukun üstünlüğü, ekonomik reformlar, yeniden yapılanma, çatışma önleme ve güvenlik reformları gibi uluslararası inisiyatiflerin ya katılımcısı ya da öznesi olmayı seçmişlerdir.

Neticede demokrasinin insanı ve bireyi merkeze alan, insanların güven içinde olabilmeleri için özgürlük ve eşitlik gibi gerekli ön koşulların varlığını şart koşan bir yönetim biçimi olduğu göz önüne alındığında, devletçi geleneksel güvenlik anlayışıyla çelişebildiği gözden kaçmamaktadır. Ancak zaman içerisinde değişen güvenlik paradigması da artık devlet merkezli güvenlik anlayışının çözüm mekanizmalarının günümüz güvenlik ihtiyaçlarına yanıt vermediğini göstermektedir.

Turizm faaliyeti kapsamında dünyada milyonlarca insanın yer değiştirmesi, geçici sürelerle de olsa kendi ülkeleri dışında yaşaması aynı zamanda hem iç güvenliği hem de uluslararası siyasal ilişkileri yakından ilgilendiren bir olgu halini almaktadır. Bu noktada turizmle birlikte ortaya çıkan insan hareketliliğinin daha özgür biçimde devamının ve artırılmasının ekonomik faydası ile bu hareketliliğin getirdiği güvenlik tehditleri karşısında denetim ve gözetim faaliyetlerinin artırılmasını da beraberinde getirmektedir. Bu gözetim ve denetim mekanizmalarının demokratikliği ise devletlere güvenliközgürlük ikileminde herhangi bir tercihte bulunmadan bir denge göz etme fırsatı sunmaktadır.

\section{Turizmin Özgürlükle İlgili Genel Unsurları}

Turizm, insanların gittikçe artan yer değişimi, dinlenme gereksinimleri, doğa ve sanatla beslenen göz alıcı güzellikleri tanıma isteği, doğanın insanlara mutluluk verdiği inancına dayanan ve özellikle ticaret ve sanayinin gelişmesi ile ulaşım araçlarının kusursuz hâle gelmelerinin bir sonucu olarak ulusların ve toplulukların birbirlerine daha çok yaklaşmasına olanak veren modern çağa özgü bir olgu olarak tanımlanmaktadır (Kozak ve Kozak, 2015:1). Tanımının içerdiği kavram ve olgular gereği turizm, kaçınılmaz olarak özgürlük kavramıyla da yakından ilişkilidir. Keza vaadi bireyin bulunduğu yerden gönüllü olarak uzaklaşma ihtiyacına dayanan turizm faaliyeti aynı zamanda özgür olma arzusuyla da eşgüdümlüdür. Turistlerin motivasyonları, faaliyetleri ve deneyimleri aynı zamanda özgürlüklerini 
kullanarak bu özgürlüklerin kısıtlanmayacağına inandıkları varış yerlerine doğru şekillenmekte ve beraberinde özgürlüğe yönelik talepkârlığı da içermektedir.

Turizm faaliyetinin kapsamı açısından bakıldığında öncelikle seyahat özgürlüğü, temel bir insan hakkı olarak kabul edilmektedir. İnsan Hakları Evrensel Bildirgesi'nin 13. maddesinde "Herkesin bir devletin toprakları üzerinde serbestçe dolaşma ve oturma hakkı vardır. Herkes, kendi ülkesi de dâhil olmak üzere, herhangi bir ülkeden ayrılmak ve ülkesine yeniden dönmek hakkına sahiptir" (UNICEF, 2020). İfadesiyle bir anlamda turizm faaliyeti de temel haklar kapsamında ele alınmıştır. Egemen devletlerin bazı durumlarda temel hak ve özgürlükleri kısıtlayabileceği de bilinmektedir ki bu durumların en önde gelen örneği güvenlik meselesi olmaktadır. Dolayısıyla seyahat özgürlüğünün korunması turizm faaliyetlerini geliştirip artırırken güvenlikçi yaklaşımların turistik faaliyetlere ket vurabileceği aşikârdır. Bu noktada turizmin özgürlük sorunsalını farklı kuramlar perspektifinde yeniden ele almakta fayda görülmektedir. Bu kuramlar arasında ise özellikle sosyal inşacılık çerçevesinde turizmin içerdiği ve meydana getirdiği özgürlük kavramını öne sürmek mümkündür (Williams ve Balaz, 2015).

Sosyal inşacı kuramın temel kabulü değerlerin toplum ve bireyler üzerinden tarihi ve kültürel olarak kurgulanan ve değişken olduğu varsayımıdır. Sosyal inşacı kuram çerçevesinde turizmin bireylerin özgürlükleri ve bu özgürlüklerin riski konusunda yapılmış pek çok araştırma mevcuttur (Löfgrden, 1999; Lyng 2008; Williams ve Balaz, 2015). Örneğin, Williams ve Balaz'a göre (2015: 33) turistler ile diğer insanlar arasındaki ilişkilerde özgürlük gergin alanlar yaratır, öyle ki bulundukları yerde geldikleri yerden daha özgür hareket etme eğiliminde bulunan turistler çoğu zaman yerel halk tarafından kısıtlanma ve yönetilme tavrıyla karşılaşmaktadır. Diğer taraftan yeni kültür ve coğrafyaları keşfetme faaliyetlerini sürdürürken turistler kendi kültürel değerlerini de yerel halka taşırlar ki böyle durumlarda ülkelerin turistik beldeleri olarak tanınan mecralardaki sosyal ilişkiler ve yapıların ülkenin geri kalanından farklılaşması mümkündür. Turizmin özgürlükçü etkisine karşı bazen yerel halk geleneksel değerlerinden kopmak ya da bazen tamamen geleneksel değerlerine daha sıkı sıkıya bağlanmak şeklinde tepkiler gösterebilir. Hughes (1998:18) özellikle küçük turistik beldelerdeki sosyal yapı değişiminin daha çok, turistlerin özgürlüğe bağlı bazı faaliyet ve davranışlarının yerel halk tarafından yadsınarak onları "diğerleri" gibi görme eğiliminde gerçekleştiğini ve yerel halkın daha muhafazakâr bir eğilime sahip olduğunu iddia etmektedir. Bir diğer deyişle özellikle yurtdışı turizm faaliyetleri bir anlamda turistlerin özgürlügü ile ülkelerin kendi vatandaşlarını özgürlügü arasında da bir gerilim alanı oluşturabilmektedir.

Turistlerin doğa üzerindeki etkileri de pek çok araştırmaya konu olmuştur. Örneğin, Williams ve Balaz (2015: 282), tekne sahiplerinin "bozulmamış" doğayı keşfetme yeteneği açısından özgürlüğü ifade edebileceklerini belirtirken, bu tür serbest dolaşımların neden olduğu atık ve çevresel bozulmanın gerçekliğini ortaya çıkarmaktadır. Yine yaptıkları araştırmada Jogaratnam ve Tse (2004) turistlerin kendi ülkelerinde gerçekleştiremediği doğayla ilişkisinin çeşitli Asya pasifik ve Afrika ülkelerindeki turistik tesislerde gerçekleştirildiğini bu durumun sahil kirlenmesi, ormanların yok edilmesi başta olmak üzere yerli halkın mülkiyet hakları üzerinde de bir gerginlik alanı oluşturduğunu ortaya koymaktadır. Benzer şekilde, daha fazla turist çekebilmek adına seyahat rehberlerinde oluşturulan özgürleştirici söylemin, gezginleri sürekli olarak yerli halkın tabi olduğu ahlaki sözleşmelerden muaf tutarak turistin 'özgürlük' arayışını üstün kıldığını ileri sürmektedir (Williams ve Balaz, 2015). Bu duruma örnek olarak halkının önemli bir kısmı Müslüman olan Maldivler, Birleşik Arap Emirlikleri gibi ülkelerde sadece turistlere içki içme özgürlügü tanınması örnek olarak gösterilebilir. Dolayısıyla, turizm uygulamaları büyük ölçüde, yerli aktörler, kültürler ve çevreler üzerindeki kısıtlamaların bir parçası olarak yer alabilmektedir.

Turizmin özgürlüklerle ilgili bir başka versiyonu ise ülkeler kendilerine daha fazla turist çekebilmek adına yaptıkları tanıtımlarda turizm ürününü özgürce bir kaçış şekli olarak pazarlamak istemekte ve turistik alanlarını problem bulunmayan alanlar inşa etmeleridir. Böyle durumlarda ise ülkelerin 
ekonomik zorlukları, tarihsel sömürü ve diğer gömülü güç ilişkileri görünmez olmaktadır. Turistlerin ziyaret ettikleri kültürler hakkında gördükleri, deneyimledikleri ve öğrendikleri, çoğu zaman kültürel başkalarının mevcut görüntü temsil ve yorumlama yapıları tarafından koşullandırılmaktadır. Günümüzde Fransız ve İtalyan sömürgeleri altında yıllarca ezilmiş olan kuzey Afrika ülkeleri, tarihi eserleri İngilizler tarafından yağmalanmış Mısır gibi ülkeler turizm faaliyetlerinde daha fazla yabancı turist çekebilmek adına kendi özgürleştirici doğalarındaki sorunları görmezden gelebilmektedir. Gonzalez (2015: 28), Filipinler'in ünlü turizm merkezlerinden ve tropik sahilin modern turist hareketliliğinin bir sembolü olan Boracay Adası'nın turizm güvenliği üzerine yaptığı bir çalışmada neoliberal ekonominin söz konusu ada gibi önemli turistik yerlerin hem güzelleştirilmesini sağlayan hem de tehdit eden geniş sosyal ve politik asimetrilerine değinmiştir. Gonzales'in (2015) çalışmasında Boracak Adası plajlarının yabancı turistlerin arzusu ve güvenliği için değişime uğrarken aynı zamanda bu değişimlerin yerli sakinlerin tehdidi ve haklarının ihlaline de evrildiğini göstermektedir (Gonzales, 2015: 232-33). Kısacası özgürlük kavramı turizm pratiğinde yer alan gerginlik veya çelişkilere önemli ölçüde ev sahipliği yapabilmektedir. Bununla birlikte, literatürün bu kısa incelemesi göstermektedir ki az sayıda çalışma açıkça özgürlük kavramını veya turistlerin özgürlüğü ile başkalarının özgürlüğü arasındaki etkileşimi ele almaktadır. Bu, bir özgürlük söylemi içinde turizmin yerleşikliği ışığında literatürde önemli bir boşluğa işaret etmektedir.

Modern turizm endüstrisi esasında liberal bir piyasa diliyle karakterize edilmektedir. Bireylerin özgürlük haklarını kullandığı bir arena olarak turizm hakkında genel bir farkındalık geliştirilmesi önemlidir. Özgürlüğü doğrudan ele alan turizm çalışmaları, oldukça geçerli nedenlerden ötürü, ya bir turizm türünü (örneğin, sırt çantası ya da macera turizmi) ya da 'özgünlük' gibi bir temayı dikkate almıştır. Bununla birlikte, özgürlük turizm pazarının birçok alanını iç içe geçiren akışkan bir kavramdır. Dahası, var olan turizm endüstrisi ülkelerde belirli bir turizm kategorisine (örneğin, bağımsız, kültürel, savaş, tarihi, macera, lüks, vb.) büyük ölçüde metalaştırılmış bir bakış açısından dayanmaktadır. Bu nedenle, turizmde daha kapsamlı bir özgürlük anlayışı geliştirecek ve turizm araştırmalarında özgürlüğü daha dürüst bir şekilde ön plana çıkaracaksak, özgürlük söyleminin varlığını ve sonuçlarını daha sistematik bir şekilde araştırmaya açı bir ihtiyaç bulunmaktadır. Zira özgürlügün güvenlikle kurduğu ilişki sadece askeri ya da geleneksel güvenlik tehditleri kapsamında değil, ekonomik sömürü, kültürel deformasyon gibi yerel halk üzerinde somut olmayan güvenlik risklerini de barındırmaktadır.

\section{Turizmin Devletler Açısından İçerdiği Güvenlik Risk ve Tehditleri}

Turizm ve güvenlik birbiriyle ilişkilidir ve ayrılmaz. Turistlerin güvenliği, ev sahibi ülkede tekrar harcama yapabilmeleri, ülkeyi yeniden ziyaret etmeleri ve bu esnada kendilerini güvende hissettikleri yerler olmaları için turizm ekonomisine önem veren her ülkenin öncelikli kaygısı olduğunu ileri sürmek mümkündür. Çoğu ülke mevcut ekonomik krizleri bertaraf etmek ve sıcak para girişini temin etmek maksadıyla dış kazanç elde etmek için turizm sektörünün gelişimini hedef almaktadır. Daha fazla yabancı turist çekme gayesiyle ise devlet politikalarının ülkeye giriş çıkışları kolaylaştıran değişimlerini gözlemlemek mümkündür. Serbest dolaşıma ve turist hareketliliğine ilişkin söz konusu kolaylaştırıcı politikalar turizm hacmini artırmada kısa vadede başarılı olmakla birlikte, çoğu ülkede bu kolaylıkların aynı zamanda ulusal güvenliği olumsuz etkileyen yönleri de gündeme gelmektedir.

Turizm içerdiği her zaman somut olmayan doğası nedeniyle farklı risk ve güvenlik tehditlerine sahiptir (Sirakaya ve Woodside 2005: 816). Turizmin soyut doğasından kastedilen öncelikli olarak bireylerin hakkında bilgi sahibi olduğu tanıdık yerlerden hakkında bilgi sahibi olmadıkları "yabancı" yerlere seyahati içermektedir (Williams ve Baláž, 2012). Diğer tarafta turistik faaliyetler çerçevesinde - özellikle de dış turizm noktasında- devletler açısından kendi vatandaşları olmayan kişilerin sınırlarından girişi ve hareketliliği de söz konusu olup bu da farklı belirsizlikleri içermektedir. Kültürler ve kurumlar hakkında bilgi edinme turizm vasıtasıyla yabancı yerleri ziyaret eden turistler için talep edilmektedir ki bu bilginin nasıl ve ne tür bir amaçla elde edileceği devletler açısından belirsizdir. Örneğin Björk ve 
Kauppinen-Räisänen (2012), gezginlerin çeşitli ülke seyahatlerinde kaydettikleri görüntülerin sosyal medyada genellikle en olumlu ya da en olumsuz olayların paylaşımı eğiliminde olduğunu bunun özellikle ülkeler hakkındaki genel algı yönetimini kontrol edilemeyen mecraya sürükleyebildiğini öne sürmektedir. Bunlar, turistin neyi görmesi gerektiği, aynı zamanda nelerden kaçınmaları gerektiği konusunda normatif rehberler sağlamakta olup bunun ev sahibi ülke dışında denetlenemeyen bir mecrada olması şüphesiz çeşitli olumsuzlukları da beraberinde getirebilmektedir. Nedenle bunlar 'turistik sosyal konunun bir aracıdır. Benzer şekilde ülkelerin askeri tesisler, kamu binaları, mekan içi, kültürel ve tarihi binaları ve özellik arz eden unsurlarına dair görüntülerin sosyal medya yoluyla paylaşılması bu konuda görüntü istihbaratı için de önemli bir malzeme oluşturmaktadır.

Her ne kadar birbiriyle ilk bakışta ilgili görünmediği düşünülen iki farklı olgu halinde gerçekleşse de terörizm ile turizm arasında birbirini yakından etkileyen ve ilişkili alanlar bulunmaktadır. Öncelikle gerek turizm gerekse terörizm günümüzde küreselleşme ile hız kazanan ulusal ve uluslararası düzeyde etki alanları bulunan teknolojik gelişmeler ve iletişim araçlarındaki yeniliklerden doğrudan etkilenen ve devletlerin denetim ve gözetim altında tutmak istedikleri faaliyetlerdir.

Turizm ve terörizm faaliyetleri aynı zamanda birbirinin hem sebebi ve sonucu olabilmektedir. Öyle ki turizm faaliyetlerinin yoğun olduğu bölgeler terör örgütleri açısından eylemlerinin sesini ve etkilerini uluslararası ortamda daha fazla duyurmak için seçilen alanlar olarak risk bölgelerini oluşturmaktadır. Terör olaylarının gerçekleştiği yerler ise içerdiği her türlü doğal, kültürel ve tarihi zenginliğe rağmen turizm faaliyetleri açısından tercih edilmeyen yerler haline gelmektedir. Terörizmle turizm arasındaki ilişkiyi Kaya (2018: 2235) şu şekilde ifade etmektedir:

“Dünya Turizm Örgütü'ne (2016) göre 2015 yllında turistik hareketlikleri etkileyen üç temel unsur bulunmaktadır. Bunlar; döviz kurlarında yaşanan olağan dışı dalgalanmalar, petrol fiyatları ve emtia fiyatlarında yaşanan düşüş ve güvenliktir. Nitekim 2015 yılı turizm verilerini ülkelere göre incelediğimizde güvenlik endişesi nedeniyle terör saldırılarının hedefi olan Fransa (\%3) ve Belçika (\%2) dünya ortalamasının altında bir yükseliş göstermiştir. Benzer şekilde terör saldırılarının hedefindeki Batı Avrupa ülkelerinin geneli \%3'lük büyümeyle dünya ortalamasının altında kalmıştır. Önemli terör saldırılarına maruz kalan Türkiye'de ise gelen turist sayısı 2014 yılına göre \%0,8 azalmıştır. Kuzey Afrika'da \%12'lik düşüş ve Orta Doğu bölgesinde ise \%2'lik artışla 53 milyon kişiye yükselmiştir. Bu yönüyle terör saldırılarının küresel turizm hareketlerini engelleyemediği ancak destinasyon tercihine etkisi olduğu ifade edilebilir."

Lisle (2013) Ekim 2002'de Bali'de ve bir ay sonra Mombasa'da otel, pub ve gece kulüplerinin terörist bombalamalarının turizm endüstrisinin 11 Eylül sonrası güvenlikleştirilmesinde başlangıç olduğunu ileri sürmektedir. Turizm ve terörizm uygulamaları, biri seyahat ve eğlenceye adanmış, diğeri politik şiddete adanmış gibi görünse de turistlerin ve turizm çalışanlarının günlük yaşamlarını devletlerin terörle mücadele müdahalelerinde etkisinin en belirgin hissedildiği alanlar olarak ortaya çıkmaktadır. Terörle mücadele yürüten küresel bir güvenlik aygıtının yörüngesinde turizm endüstrisinin maddi altyapısı önemli bir kırılma noktasıdır. Uluslararası ilişkiler ve coğrafyadaki kritik çalışmalardan yola çıkarak aslında liberal düzenin istisnai bir terörist tehdit üreterek zararlı yönetim biçimlerini içerdiği çok daha geniş bir mantığın bir parçası olarak turizmin giderek daha fazla güvenlikleştirildiği söylenebilir (Lisle, 2013: 130). Bu mantığın küresel gezginler tarafından sembolize edilen kozmopolit bir topluluk aracılığıyla yeniden üretildiği göz önüne alındığında turizm endüstrisi tarafından alınan otel altyapısının fiziksel dönüşümleri ve çalışanların terörle mücadele eğitiminin sağlanması önlemler de artmaktadir.

Günümüzde terör eylemlerinin, özellikle turistik bölgelere ve tüketicilere yönelmesinin sebepleri olarak belirli etmenlerden bahsetmek mümkündür. Öncelikle bir ülkenin turistik bölge veya destinasyonuna yapılan saldırılar, tüm ülke ekonomisini olumsuz olarak etkileyebilmektedir. Örneğin 2015 yılında 
Fransa'da yaşanan Bataclan saldırılarından sonra insanların eğlence merkezlerine (sinema, konser, tiyatro, spor karşılaşmaları) gitmemesi sonucunda ülkedeki taşımacılık, konaklama, gıda hizmeti veren sektörler oldukça olumsuz etkilenmiş ve bir süre ülkede ekonomik durgunluk baş göstermiştir (Tarlow, 2002: 49).

Turizm sektörünün gelişmesi için devletler oldukça ciddi tedbirler almaktadır ve bu alana önemli kaynak aktarımı yapılmaktadır. Aynı zamanda turizm ülkelerin bir nevi itibar noktası olduğu için, bu noktalara yapılan saldırılar direk devlete yapılmış olarak kabul görmektedir. Ayrıca turizme yapılan terör saldırıları basında çabuk yer almakta bu nedenle turistik alanlara veya turizm sektöründe yapılan bir eylem küresel çapta ses getirecek olup, eylemciler tarafında verilmek istenen mesaj yerine ulaşmış olacağı için turistik alanlar teröristler tarafından daha fazla hedef halini almaktadır. Bunun yanı sıra bir ülkede veya destinasyonda bulunan kültürel mirasa, müzeye, turistik veya benzeri alana yapılacak terörist saldırıları ile buraların zarara uğratılması, terör eylemini gerçekleştirenler için ilgi toplamanın en kolay yolu olarak görülmektedir.

Tablo 1. Küresel Terör Eylemleri (2001-2015)

\begin{tabular}{|c|c|}
\hline Yil & Terör olayı \\
\hline 2001 & Amerikan havayollarının bombalanması \\
\hline 2002 & $\begin{array}{l}\text { Pakistan/Karachi'de otobüse bombalı saldırı, Bali'de ilk bombalı saldırı, } \\
\text { Kenya/Mombasa'ya füze saldırıları ve intihar saldırısı }\end{array}$ \\
\hline 2003 & $\begin{array}{l}\text { Filipinler/Davao havalimanının bombalanması, Casablanca bombalanması, } \\
\text { Endonezya/Marriott Otel bombalanması, Irak/Canal Otel bombalanması, } \\
\text { Türkiye'de Bethİsrael Sinagogu, 2. Neve Şalom Sinagogu, İngiltere İstanbul } \\
\text { Başkonsolosluğu ve HSBC Bankası Genel Müdürlüğüne yapılan bombalı } \\
\text { saldırılar }\end{array}$ \\
\hline 2004 & $\begin{array}{l}\text { Filipinler'de gemi bombalanması, Rusya'da iki havalimanının bombalanması, } \\
\text { İsrail/ Sinai bombalanması }\end{array}$ \\
\hline 2005 & $\begin{array}{l}\text { Misır/Sharm El-Sheikh bombalanması, Bali'nin ikinci kez bombalanması, } \\
\text { Ürdün/Amman'ın bombalanması, Türkiye'de Kuşadası'nda otobüsün } \\
\text { patlatılması }\end{array}$ \\
\hline 2006 & $\begin{array}{l}\text { Mısır/Dahap'ın bombalanması, Transatlantik havayollarına yapılan saldırı, } \\
\text { Ürdün/Amman'da silahlı saldırı, Türkiye'de Marmaris' otel saldırısı ve } \\
\text { Antalya Dönerciler Çarşısı saldırısı }\end{array}$ \\
\hline 2009 & Mısır/Kahire/Han Halili bombalı saldırısı \\
\hline 2015 & $\begin{array}{l}\text { Tunus/Müze Saldırısı, Tunus/Susa Hoteli Plajı silahlı saldırısı, } \\
\text { Tayland/Bangkok Erawan Tapınağı bombalı saldırısı, Sina Yarımadası/ Rus } \\
\text { Metrojet Havayolları uçak saldırısı }\end{array}$ \\
\hline
\end{tabular}

Kaynak: Acar ve Çetin, 2017; Bağçı, 2017 ve www.bbc.com dan derlenmiştir. 
Turizm destinasyonlarında, özgürlük alanlarındaki güvenlik açıklarını kullanma ve tedbirlerin çok daha seyrek olacağı düşüncesi, terör eylemcilerini bu alanlara sevk etmektedir. Eylemcilerin, kamufle teknik ve yöntemleri, turizm sektörünü terörist saldırılar için açık hedef haline getirmektedir. Özellikle radikal dinci terörist grupların, uluslararası turizmin, Batı' yı ve yozlaşmayı temsil ettiği düşüncesi, terör eylemlerinde öncelikli olarak turist gruplarının hedef alınmasına neden olmaktadır.

Turizmin, ekonomilerine önemli katkıda bulunan ülkelere yapılan terör saldırıları son yıllarda artış göstermektedir. Özellikle 11 Eylül saldırılarından sonra, terör eylemlerinin gerçekleştirilme şekli ve yeri, ülkeleri ve devletleri önlem alma konusunda zorlamaktadır (Koçak ve Memiş, 2017; Hayes, 2005). Günümüzde terör saldırılarının en büyük hedefi kalabalık kitleler ve alanlardır. Terör eylemcileri artık eskisi gibi sadece güvenlik güçlerini veya devlet görevlilerini hedef almamaktadırlar. Kendi amaçları doğrultusunda, yerel veya enternasyonal düzeyde maksimum etkiyi yapabilecek eylemler yapmaktadırlar. Bundan dolayı terör eylemlerinde hedef giderek daha fazla turistik faaliyetlerin yoğun yaşandığı yerler olmaktadır. 11 Eylül sonrası özellikle turizmi doğrudan etkilen terör olaylarına şu örnekleri vermek mümkündür:

Söz konusu terör olaylarında çoğu ülkelerdeki turistler olmak üzere toplamda iki bine yakın kişi hayatını kaybetmiş, beş bin kişinin üzerinde kişi yaralanmıştır (Bağçı, 2017; Acar ve Çetin, 2017). Turistik bölgelerde, turistlerin rahatllğg açısından, güvenlik tedbirlerinin çok sıkı olmayacağı düşüncesi, terör eylemcilerini bu alanlara sevk etmektedir. Eylemcilerin, turistlerin arasında dikkat çekmeden gizlenebilmesi, turizm sektörünü terörist saldırılar için açık bir hedef haline getirdiği düşünülmektedir. Özellikle radikal dinci terörist gruplar için, uluslararası turizmin Batı'yı ve yozlaşmayı temsil ettiğini düşündüklerinden, terör eylemlerinde öncelikli olarak bu kitlenin hedef alınmasına neden olabilmektedir.

Neocleous (2008:8), güvenliğe toplumun biçimlenmesine ve siyasal yönden düzenin yeniden kendini üretmesine imkân sağlayan bir olgu olarak bakmakta ve devleti güvenlik risklerini ve tedbirlerini belirleyen ardından da güvenlik güçlerini yayan bir düzen aracı olarak tanımlamaktadır. Devletin kamu düzenini sağlama adına kullandığı araçsal kurumlar ise güvenlik teşkilatları olmaktadır. Bu çerçevede turizm bölgelerinin içerdiği güvenlik tehditleri ekseninde devletlerin özellikle 2001 yılı sonrası aldığı iç güvenlik önlemlerinin uygulanmasında kolluk faaliyetleri oldukça önem kazanmıştır.

Turizm alanlarının özgürlüğünün korunması ve güvenliğinin sağlanması konusunda halkın emniyetinin sağlanması ve kaostan yararlanarak işlenecek olası suçlarla mücadele kolluğun bu süreçteki temel görevleri arasında yer almaktadır. Dolayısıyla başta havalimanlarındaki giriş ve çıkışlarda kontrollerin artırılması, denetim ve gözetim faaliyetlerine verilen önem ile turizmin içerdiği güvenlik tehditlerinin devletleri "koruma" ve "önleme" faaliyetleri üzerine odaklandırdığını söylemek olanaklıdır.

\section{SONUÇ ve ÖNERILER}

Turizm doğası gereği bireysel özgürlük, zevk ve boş zaman etkinlikleri ile ilişkili görülüp içerdiği güvenlik risk ve tehditleri çoğunlukla göz ardı edilmektedir. Tehdit ve riskler esasen hazzın karşıtı olarak kabul edildiği için özellikle kitlesel memnuniyet verici turizm görünürde riskin yokluğu üzerine kurgulanmaktadır. Devletler turizm güvenliği politikalarını her ne kadar turistin güvenliği üzerine odaklasalar da bu çalışma göstermektedir ki turizmin ekonomik faydaları ancak devletin ve yerel halkın güvenliğinin sağlanmasından bağımsız değildir. Zira turizmin hem özgürlük hem de güvenlik ilişkisi çerçevesinde sürekli mevcut ama görünenin altında yer alan potansiyel tehditleri mevcuttur.

Öncelikle turistik faaliyetlerle ilgili risk ve belirsizliğin var olduğu kabulü, turizmin doğası ve derinlemesine anlaşılması için önemli bir bakış açısı sağlamaktadır. Turizm sektörünün özel doğası, turizmde risk ve belirsizlik için ilave önlemlerin de alınmasını gerektirmektedir. Turizmin karmaşık 
doğası, seyahat özgürlüğü çerçevesinde sınırları aşmanın ve zımni bilgi alanlarından kaynaklanan deneyimlerin denetim ve kontrol mekanizmalarını da bazen devre dışı bırakabilmektedir. Doğası gereği turizm dünya çapında ve rekabet gücü yüksek bir sektördür. Her ne kadar doğal olarak ekonomik krize, doğal felaketlere ve savaş ve salgın hastalık salgınlarına maruz kalsa da uluslararası turizm bu tür zararlı ancak kısa vadeli faktörlerin olumsuz etkilerinden kurtulmada önemli bir esneklik göstermiştir. Bununla birlikte turizm tehlike algılarına, güvenlik ve emniyet eksikliğine karşı oldukça duyarlıdır. Bu çerçevede, güvenlik ve emniyet eksikliğinin ve suç oluşumlarının, seyahat ve turizm için diğer olumsuz faktörlerden daha ciddi bir tehdit oluşturduğu görülmektedir. Günümüzde turizm ülkelerin önemli gelir kaynaklarından biri olarak desteklenen ve yükselen bir ivme taşımakla birlikte güvenlik risk ve tehditlerinden yüksek derecede etkilenen -ve aynı zamanda da bu etkileri kendi taşıyan- kırılgan bir gelir kaynağı olarak özellikle devletlerin her konuda geniş bakış açısıyla yönetmeleri gereken bir sektördür.

$\mathrm{Bu}$ çalışmada varılan temel sonuç turizmin özgürlük ve güvenlikle olan ilişkisinde tek yönlü bakış açısının yeterli olmayacağıdır. Diğer bir deyişle ülkelerin turizmi geliştirmek için sağladıkları özgürlük ve güvenlik ortamının öneminin yanı sıra turizmin gelişiminden kaynaklanan yerel halkın özgürlüğü ve devletin güvenliğine yönelik risk ve tehditlerin de görmezden gelinmemesi gerekmektedir. Zira günümüzde temel güvenlik tehditleri arasında yer alan salgın hastalıklar, terör faaliyetleri, kamu düzeninin bozulması ve çevre güvenliği gibi unsurlar hem turizmin gelişimi engelleyen aynı zamanda da turizmin gelişimi ile de artan tehdit ve riskler içermektedir.

Özgürlük ve güvenlik kavramlarının turizm sektörü içindeki konumlanması bu çalışmanın sınırlılığını oluşturmaktadır. Bundan sonraki araştırmalarda, belirli bir ya da birkaç destinasyon özelinde, güvenlik ve özgürlük ikileminin bölge halkı ya da turizm bileşenleri açısından getirdiği sonuçların faydalı olacağı düşünülmektedir.

Günümüzde turizm ülkelerin önemli gelir kaynaklarından biri olarak desteklenen ve yükselen bir ivme taşımakla birlikte güvenlik risk ve tehditlerinden yüksek derecede etkilenen -ve aynı zamanda da bu etkileri kendi taşıyan- kırılgan bir gelir kaynağı olarak özellikle devletlerin her konuda geniş bakış açısıyla yönetmeleri gereken bir sektördür. Özellikle Türkiye başta olmak üzere Akdeniz, Ortadoğu ve Avrupa ülkeleri gibi pek çok turizm ekonomisinin güçlü olduğu ülkelerde turizmin gelişiminin ancak güvenli ortamlarda ivme kazandığı göz önüne alındığında geliştirilecek güvenlik önlem ve tedbirlerinin aynı zamanda özgürlüğü mümkün mertebe kısıtlamayacak bir algı çerçevesinde sürdürülmesi önem kazanmaktadır.

Bu çalışmada varılan temel sonuç turizmin özgürlük ve güvenlikle olan ilişkisinde tek yönlü bakış açısının yeterli olmayacağıdır. Diğer bir deyişle ülkelerin turizmi geliştirmek için sağladıkları özgürlük ve güvenlik ortamının öneminin yanı sıra turizmin gelişiminden kaynaklanan yerel halkın özgürlügü ve devletin güvenliğine yönelik risk ve tehditlerin de görmezden gelinmemesi gerekmektedir. Zira günümüzde temel güvenlik tehditleri arasında yer alan salgın hastalıklar, terör faaliyetleri, kamu düzeninin bozulması ve çevre güvenliği gibi unsurlar hem turizmin gelişimi engelleyen aynı zamanda da turizmin gelişimi ile de artan tehdit ve riskler içermektedir.

Ayrıca turizm endüstrisiyle güvenlik endüstrisinin günümüzde birbirinden ayrı düşünülemeyeceği göz önünde bulunulduğunda turizm sektörüne yapılan yatırımlarda güvenlikçi yaklaşımlara da önemli bir bütçe ayrılması gerektiği düşünülmektedir. Bu kapsamda ülkelerin öncelikle yaptıkları tanıtım faaliyetlerinde mevcut özgür ortam reklamlarının yanı sıra güvenli alan algısını da destekleyecek mesajların oluşturulması, devletlerarasında turist hareketliliğini bürokratik engellerden arındırarak aynı zamanda da kontrollü ve denetimli bir işbirliği gerçekleştirmeleri ile turist davranışlarına yönelik pek çok araştırmayla desteklenecek akademik çalışmalardan faydalanılması önem taşımaktadır. Diğer taraftan turizm sektörünün içerdiği fırsatlar ekseninde de güvenlik özgürlük dengesinin sağlanmasında devletlerin güvenlik güçlerinin turizm faaliyetleri ve turistle iletişim noktasında farkındalıklarının artırılması gerektiği düşünülmektedir. Küresel turizmle küresel terörizmin kesiştiği noktalarda ise öne 
çıkan güvenlikçi yaklaşımların siyasi ve ekonomik istikrar eşliğinde müdahaleci değil önleyici faaliyetler üzerine yoğunlaşmalarının da turizm endüstrisinin güvenlik-özgürlük dengesi içerisinde payının artırılmasında bir katma değer sağlayacağı değerlendirilmektedir.

\section{KAYNAKÇA}

Acar, A. ve Çetin, G. (2017). Terör ve Turizm Arasındaki Ekonomik İlişki. Journal of Recreation and Tourism Research. 4 (1): 255-274.

Bahar, O. ve Kozak, M. (2013). Turizm Ekonomisi. Eskişehir: Anadolu Üniversitesi Yayınları.

Bağçı, E. (2017). Terör Olaylarının Türkiye Turizm Sektörüne Etkisi. Yüzüncü Yıl Üniversitesi Sosyal Bilimler Dergisi. Özel sayı 3. http://www.yyusbedergisi.com/eng/dergiayrinti/the-effects-of-terrorismto-tourism-activities_192. Erişim Tarihi: 7 Mayıs 2020).

Björk, P. and Kauppinen-Räisänen, H. (2012). A Netnographic Examination of Travelers' Online Discussions of Risks. Tourism Management Perspectives, 2(3): 65-71.

Erdoğan, M. (2013). Anayasal Demokratik Bir Rejimde Özgürlük ve Güvenlik. İstanbul Ticaret Üniversitesi Sosyal Bilimler Dergisi. 12(24): 21-29.

Gonzalez V.V. (2015). Tourism Mobilities, Indigenous Claims and The Securitization of The Beach. In: Montegary L., White M.A. (Eds) Mobile Desires: The Politics and Erotics of Mobility Justice. Mobility \& Politics. Palgrave Pivot, London.

Gölpınar. H. (2019). Yeni Nesil Psikolojik Harekât ve Algı Operasyonları, (iç) Propaganda ve Alğ Yönetimi, (Ed. Muhittin Imıl), Ankara: Orion Kitabevi.

Hughes, G. (1998). Tourism and the Semiological Realization of Space. In Destinations: Cultural Landscapes of Tourism, edited by G. Ringer. London: Routledge.

32.

Haspolat, E. (2010). Türkiye'de Neoliberal Devlet Anlayışı Bağlamında, Devlet -Güvenlik İlişkisinin Değişen İçeriği ve Özel Güvenlik Olgusu. Yayımlanmamış Doktora Tezi, Ankara Üniversitesi Sosyal Bilimler Enstitüsü, Ankara.

Hayes, N. (2005), Liberty v. Security-UK Anti-Terrorism Legislation, The ECHR and The House of Lords. Trinity College Law Review. 8(5):106-129.

Jogaratnam, G. and Tse, E. C. (2004). The Entrepreneurial Approach to Hotel Operation: Evidence from the Asia-Pacific Hotel Industry. Cornell Hotel and Restaurant Administration Quarterly, 45(3): 248-59.

Kaya, O (2018). Turistlerin Terörist Saldırılara İlk Tepkileri: Atatürk Havalimanı Saldırısı Örneği. Opus Uluslararası Toplum Araştırmaları Dergisi. 9 (16): 2232-2257.

Kozak, M., ve Kozak N. (2015). Genel Turizm: Illkeler ve Kavramlar. İstanbul: Detay Yayınc1lık.

Kozak, N., Kozak, M.A. ve Kozak, M. (2014). Genel Turizm Illkeler Kavramlar. Ankara: Detay Yayıncilık.

INSEE, (2020). http://www.insee.fr/fr/methodes/default.asp?page=definitions/tourisme.htm, (Erişim tarihi: 17.04 .2020$)$

Löfgren, O. (1999). On Holiday: A History of Vacationing. Berkeley, CA: University of California Press.

Lyng, S. (2008). Edgework, Risk and Uncertainty. İç. Social Theories of Risk and Uncertainty: An Introduction, Ed. J. O. Zinn. Oxford: Blackwell, pp. 106-37.

Mirovic V., Pavlovic N and Puskaric A. (2014). Asset Securitization as A Means of Tourism Financing. Economic Insights - Trends and Challenges, 3 (2): 21-32. 
Öz Yıldız. S. (2019). Yeni Güvenlik Paradigması Ekseninde İstihbarat ve Propaganda Savaşları, (iç) Propaganda ve Algı Yönetimi, (Ed. Muhittin Imıl), Ankara: Orion Kitabevi.

Öz Yıldız, S., (2017). Demokratik Polislik: Teori ve Uygulamalar, Ankara: Polis Akademisi Yayınları.

Lisle, D. (2013). Frontline Leisure: Securitizing Tourism in The War on Terror. Security Dialogue. 44 (2): 127-146.

Sirakaya, E. and Woodside, A. G. (2005). Building a Testing Theories of Decision-Making by Travelers. Tourism Management, 26(6): 815-32.

Tutar, F., Alpaslan, C., Tutar, E. ve Erkan, Ç. (2013). Turizm Sektörünün İstihdam Üzerindeki Etkileri. Global Journal of Economics and Business Studies. 2(4): 14-27.

Tarlow, P. (2002). Event Risk Management and Safety. UK: The Wiley Event Management Series.

UNICEF,(2020).http://www.unicef.org.tr/files/bilgimerkezi/doc/insan\%20haklari\%20evrensel\%20beya nnemesi.pdf, (Erişim tarihi: 07.05.2020).

Ünlüönen, K. ve Şahin, S.K. (2011). Turizmde İstihdam. Elektronik Sosyal Bilimler Dergisi. 10(37): 1-25.

Williams, A. M. and Baláž (2015). Tourism, Risk and Uncertainty: Theoretical Reflections, Journal of Travel Research, 54(3): 271-287.

Williams, A. M. and Baláž, V. (2012). Migration, Risk and Uncertainty: Theoretical Perspectives. Population Space and Place. 18(2): 67-80. 